\title{
Current Knowledge in Physiological and Genetic Mechanisms Underpinning Tolerances to Alkaline and Saline Subsoil Constraints of Broad Acre Cropping in Dryland Regions
}

\author{
Muhammad Javid, Marc Nicolas and Rebecca Ford \\ Department of Agriculture and Food Systems, Melbourne School of Land and \\ Environment, The University of Melbourne \\ Australia
}

\section{Introduction}

Abiotic stresses are a serious problem to crop production under dryland conditions in arid and semi-arid regions of the world. These abiotic stresses include high and low temperature, water deficit, salinity, sodicity, alkalinity, acidity and ion deficiencies and toxicities. Many Australian agricultural soils accumulate salts under seasonal fluctuations and have multiple subsoil constraints such as alkalinity, acidity, sodicity, and toxic ions (Rengasamy, 2006). Of these, salinity and alkalinity are simultaneously found in soils of southern Australia (Nuttall et al., 2003a; Nuttall et al., 2003b). The simultaneous occurrence of multiple abiotic stresses may result in far greater productivity loss than any single abiotic or biotic factor.

Nearly 800 million ha of land throughout the world is salt affected either by salinity or associated with sodicity (FAO, 2009). The total area under salinity in Australia is estimated to be 32 million ha in arable and permanent cropping land (FAO, 2000). Transient or dryland salinity is probably the biggest factor causing salinity in Australia (Figure 1; Rengasamy 2002). Saline soils are generally defined as those having high concentrations of soluble salt with an electrical conductivity $\left(\mathrm{EC}_{\mathrm{e}}\right)$ of more than $4 \mathrm{dSm}^{-1}$. Among the soluble salts, $\mathrm{NaCl}$ is the major component contributing to salinity (USSL, 2005).

Yields of important cereal, oilseed and forage crops are limited by soil salinity in broad acre dryland regions. Therefore, genetic crop improvement by conventional and nonconventional methods for salt tolerance is vital to maintain food production. The ability to grow and reproduce in saline soil differs widely between species, due to differences in the ability to control salt uptake from the soil and to compartmentalise it effectively at the cellular level (Munns \& Tester, 2008).

Crops grown under dryland conditions on alkaline soils in south-eastern Australia are potentially limited by many factors, especially water supply and nutrition (Incerti \& O'Leary, 1990). Alkaline soils are usually categorized by low availability of plant nutrients, high concentrations of $\mathrm{HCO}_{3}{ }^{-}$and $\mathrm{CO}_{3}{ }^{2-}$, and high $\mathrm{pH}$ (Marschner, 1995; Misra \& Tyler, 1999). By definition, alkalinity is the concentration of soluble alkalis with the ability to neutralize acids (Bailey, 1996). Bicarbonate $\left(\mathrm{HCO}_{3}{ }^{-}\right)$and carbonate $\left(\mathrm{CO}_{3}{ }^{2-}\right)$ are the principal 
contributors to alkalinity, whereas hydroxide, borate, ammonia, organic bases, phosphates, and silicates are considered minor contributors (Petersen, 1996). This review will discuss how salinity and alkalinity affect plant growth and the different methods used to identify and improve tolerance in various crop species.

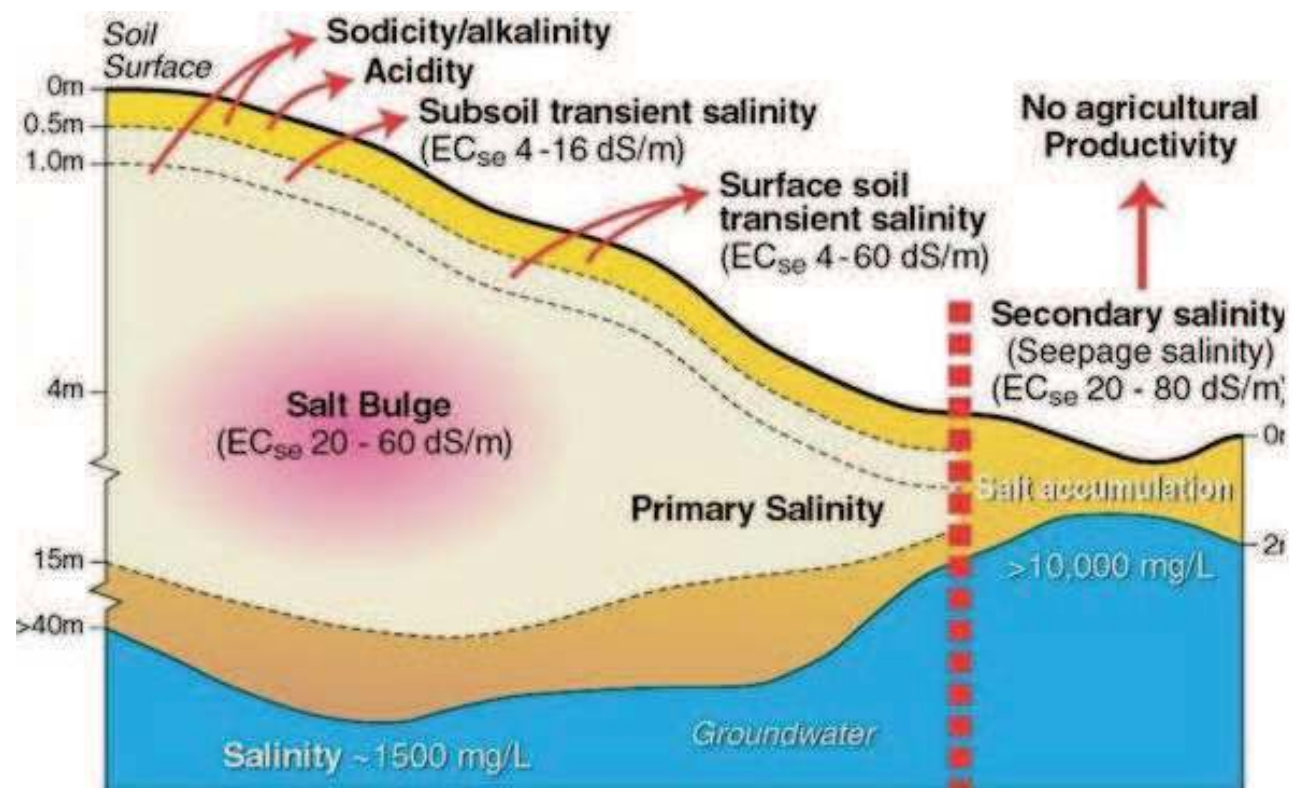

Fig. 1. Different types of salinity in Australian landscapes (after Rengasamy, 2002).

\section{Salinity effects in plants}

The most common effects of salinity on plant growth are smaller and fewer leaves, reduced plant height and poor yield (Kumar, 1995). At the physiological level, salinity imposes an osmotic stress that limits water uptake and ion toxicity can cause nutrition $(\mathrm{N}, \mathrm{Ca}, \mathrm{K}, \mathrm{P}, \mathrm{Fe}$, Zn) deficiency and oxidative stress (Munns, 2002). Salinity can differentially affect the mineral nutrition of plants. Nutrient imbalances due to salinity diminish plant growth by affecting the availability, transport, and partitioning of nutrients. Nutrient deficiencies or imbalances result due to competition of $\mathrm{Na}$ and $\mathrm{Cl}$ with other nutrients such as $\mathrm{K}, \mathrm{Ca}, \mathrm{Mg}$ and $\mathrm{NO}_{3}$ (Hasegawa \& Bressan, 2000; Hu \& Schmidhalter, 1998; Hu \& Schmidhalter, 2005; Munns, 2002; Netondo et al., 2004). These nutrient imbalances due to salinity also cause reduction in plant growth. Plant responses to salinity can vary with the degree and duration of the stress imposed as well as the plant developmental stage (seedling, flowering, maturity) when the stress is applied (Munns, 1993). To identify truly tolerant germplasm, it is important to gain full information regarding the degree of salt tolerance at all growth stages of a crop species. Otherwise selection at one particular growth stage may result in plants that lose their tolerance at other stages. 


\subsection{Mechanisms of salt tolerance}

Plants are generally categorized as either halophytes or glycophytes. Halophytes grow and survive best where salt concentration is $200 \mathrm{mM}$ or more (Flowers \& Colmer, 2008). Conversely, glycophytes cannot survive under high saline conditions (Figure 2). A major difference between halophytes and glycophytes is the ability of halophytes to survive salt shock (Braun et al., 1986; Casas et al., 1991; Hassidim et al.,. 1990).

Several mechanisms for tolerance operate in both halophytes and glycophytes and the differences are presented in Figure 3. However, the main adaptive strategies of salt-tolerant glycophytic plants exposed to salinity are: 1) avoidance through ion exclusion, potentially as a result of low membrane ion permeability; 2) tolerance, through ion inclusion and possible compartmentalisation; and 3) osmotic stress tolerance, which enables the plant to remain functional despite internal ionic stress (Blumwald et al., 2004; Munns, 2005; Munns \& Tester, 2008).

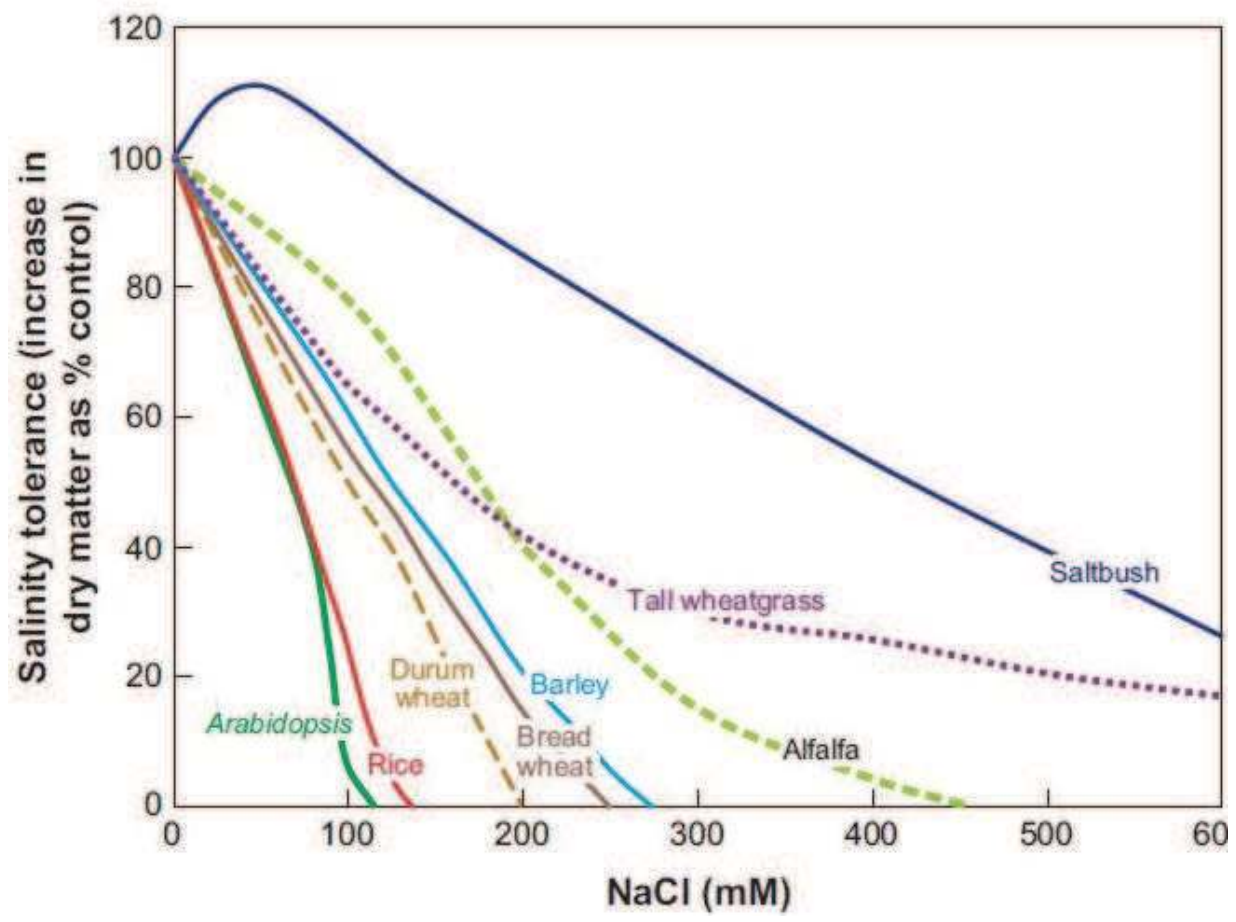

Fig. 2. Response of glycophytes and halophytes to varying concentrations of $\mathrm{NaCl}$ after 3 weeks of treatment (after Munns \& Tester, 2008). 


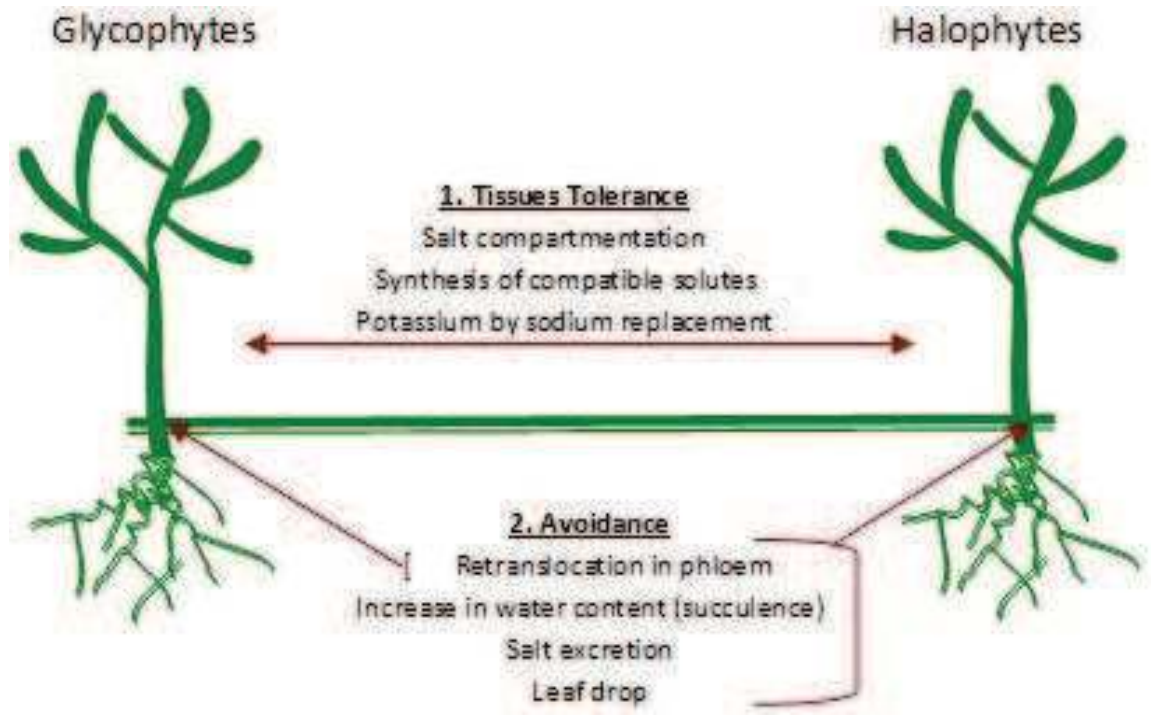

Fig. 3. Adaptive strategies for salt tolerance in plants.

\subsection{Ion exclusion}

$\mathrm{Na}$ avoidance is an essential salt tolerance mechanism that operates in several glycophytes such as; wheat (Munns, 2005; Munns \& Tester, 2008), Arabidopsis (Moller et al., 2009; Møller \& Tester, 2007), B. napus and B. juncea (Ashraf \& McNeilly, 2004; Ashraf et al. 2001). To achieve this type of tolerance, plant roots must exclude most of the $\mathrm{Na}$ and $\mathrm{Cl}$ dissolved in the soil solution, and escape from gradual build-up of salt in shoots to toxic levels (Munns, 2005). Salinity tolerance in cereals is largely contributed by Na exclusion. As plants transpire about 50 times more water than they retain in their leaves, exclusion of $98 \%(1 / 50)$ of the salt in the soil solution results in stable leaf Na concentration (Munns, 2005). For instance, bread wheat excluded $>98 \%$ of the $\mathrm{Na}$ in the soil solution, and consequently $\mathrm{Na}$ concentration build-up in leaves remained less than $50 \mathrm{mM}$ (Husain et al., 2004). Barley, on the other hand, excluded $<98 \%$ of the $\mathrm{Na}$ in the soil solution, and the concentrations reached up to $500 \mathrm{mM}$ (Rawson et al., 1988).

Salinity tolerance in B. juncea however, is achieved through partial exclusion (Ashraf \& McNeilly, 2004; Ashraf et al., 2001). In some members of the Brassicaceae including Arabidopsis, salinity tolerance appears to be mainly achieved by tissue tolerance to accumulated $\mathrm{Na}$ rather than by exclusion of $\mathrm{Na}$ from the shoot (Møller \& Tester, 2007). In two $B$. napus genotypes, the genotype with the higher $\mathrm{Na}$ accumulation in the shoot was more $\mathrm{Na}$ tolerant and also accumulated increased amounts of $\mathrm{K}$ and proline (Huang \& Redman, 1995). These results imply that tissue tolerance to $\mathrm{Na}$ and tolerance to osmotic stress are more important than $\mathrm{Na}$ exclusion from the shoot in members of the Brassicaceae.

\section{3 lon compartmentation}

Salt tolerance by compartmentation is very important mechanism that operates in many glycophytes such as Arabidopsis (Moller et al., 2009; Møller \& Tester, 2007), wheat and barley (Munns, 2005; Munns et al., 1995; Munns \& Tester, 2008), and B. juncea (Ashraf \& McNeilly, 
2004; Kumar et al.,2009). Ion specific effects of salinity primarily result in accumulation of higher levels of sodium (Na), usually in the older leaves. Entry of $\mathrm{Na}$ into the cell is due to the similarity in hydrated ionic radii between $\mathrm{Na}$ and $\mathrm{K}$ that makes it difficult for the transporters to distinguish between these two ions (Blumwald et al., 2000). To avoid deleterious Na toxicity in the cytoplasm, it must be compartmentalised into cell vacuoles (Munns \& Tester, 2008). This allows maintenance of optimum cellular levels of $\mathrm{K}$ and calcium (Ca) as well as $\mathrm{Na}$ exclusion by the plant. These two activities are known to operate at the plasma membrane and tonoplast levels, as integral components of the ion transport network. This is one of the key physiological criteria of plant salt tolerance, to maintain optimal $\mathrm{K} / \mathrm{Na}$ ratio in the cytosol (Singla-Pareek et al., 2003; Singla-Pareek et al., 2008; Tester \& Davenport, 2003). A higher K/Na ratio essentially indicates that a plant has not only excluded $\mathrm{Na}$ to some extent but has also maintained a healthy level of $\mathrm{K}$ for normal metabolic activities and injury avoidance under salinity. Hence, manipulation of the salt overly sensitive (SOS) pathway, $\mathrm{Na} / \mathrm{H}$ antiporters and/or $\mathrm{K}$ transmembrane transporters that are involved in ion homeostasis may be the target of future strategies for salt tolerance improvement in a range of crops including canola quality B. juncea (Benke et al., 2010; Blumwald et al., 2004).

The role of transport proteins such as antiporters, ion channels, ABC-type transporters, Na and $\mathrm{K}$ transporters, plasma membrane and vacuolar ATPases is fundamental for salt tolerance in $\mathrm{Na}^{+}$exclusion, ion homeostasis, and compartmentalization of solutes and amino acids under stress (Apse et al., 2003; Takahashi et al., 2009). The over-expression of vacuolar $\mathrm{Na} / \mathrm{H}$ antiporter in $B$. napus greatly diminished the salt-induced oxidative stress in the vacuoles, highlighting the importance of $\mathrm{Na}$ homeostasis during salt stress tolerance (Ruiz \& Blumwald, 2002; Zhang et al., 2001b). The Arabidopsis thaliana vacuolar alkali cation transporter AtNHX1 has been shown to increase salt tolerance in transgenic plants through the intracellular compartmentation of $\mathrm{Na}$ (Apse et al., 1999; Hernández et al. ,2009; Venema et al., 2002).

\subsection{Osmotic adjustment}

Salinity is a common feature of arid and semiarid lands, and plants have evolved mechanisms to tolerate the low soil water potential caused by salinity, as well as by drought, and so some level of tolerance to osmotic stress is a feature of most glycophytes and halophytes (Munns \& Tester, 2008). Osmotic adjustment in plants exposed to salt stress helps to maintain turgor pressure, which consequently helps plant to achieve tolerance under saline conditions (Ashraf \& McNeilly, 2004). A significant genetic variation within species may exist in the osmotic response under saline stress; however this has not yet been documented (Munns \& Tester, 2008). In salt sensitive plants, low water potential caused by salinity stress leads to cell membrane damage causing ion toxicity and cell injury (Chen \& Murata, 2002; Sreenivasulu et al., 2000). This primarily results in smaller leaves and reduction in leaf area in many crops. Reduction in leaf area development and relative root growth might decrease the water use by the plant, which allows it to preserve soil moisture and avoid an escalation in the salt concentration in the soil (Munns \& Tester, 2008). Osmotic adjustment occurs in plants subjected to saline stress, but particularly to a large extent in salt-tolerant Brassica species (Ashraf \& McNeilly, 2004).

This is primarily due to accumulation of different types of organic osmotica such as soluble sugars, free amino acids and free proline in most of the salt-tolerant Brassica species (Ashraf \& Akram, 2009; Ashraf \& McNeilly, 2004). The relative importance of variation in osmotic tolerance remains unknown for most crop species, due to inherent difficulties in quantifying this parameter. However, a close association is likely exists between osmotic tolerance and 
tissue tolerance of $\mathrm{Na}^{+}$, because genotypes that tolerate high internal $\mathrm{Na}^{+}$concentrations in leaves by compartmentalizing it in the vacuole may also be more tolerant of the osmotic stress owing to their elevated osmotic adjustment (Munns \& Tester, 2008). However, this theory needs further investigation.

\subsection{Molecular control of salt tolerance}

The adaptive physiological and biochemical responses of a plant to salinity are controlled by genes that encode salt tolerance mechanisms (Casas et al., 1992). Since salinity tolerance is a complex trait, it is most likely controlled by interactions of hundreds of salt responsive genes (Sahi et al., 2006; Winicov, 1998). Plants recognise a salinity stress and condition adaptive response mechanisms (Hasegawa \& Bressan, 2000). Reported responses involve many molecular processes such as ion homeostasis (membrane proteins involved in ionic transport), osmotic adjustment and water regime regulation (osmolytes), as well as scavenging of toxic compounds (enzymes; Benke et al., 2010; Blumwald et al., 2004). The regulatory molecules conditioning these responses have been found to be cellular signal pathway components and transductors of long distance response co-ordination such as hormones, mediators, transcription factors and regulatory genes (Mishra et al., 2006). The expression of such genetic regulators during plant stress has been studied at the transcriptional level (Fernandez et al., 2008; Hasegawa \& Bressan, 2000). Consequently, abiotic stress-inducible genes have been classified into two categories; 1 ) those that directly protect against environmental stress; and 2) those that regulate gene expression and signal transduction against stress response (Hasegawa \& Bressan, 2000; Kawaura et al., 2008; Mishra et al., 2006; Popova et al., 2008; Ueda et al., 2002). Some of the major genes/proteins that are activated under salinity might be involved in tolerance (Table 1). Hence, it is imperative to analyse the functions of stress-inducible genes for amplification of the molecular mechanisms of stress tolerance in plants.

Salt tolerance is attained through three interrelated characteristics; the foremost, salt injury must be avoided or alleviated. Second, homeostatic conditions must be re-established in the new stressful environment. Third, growth must resume, even if at a reduced rate (Fig. 4; Zhu, 2001).

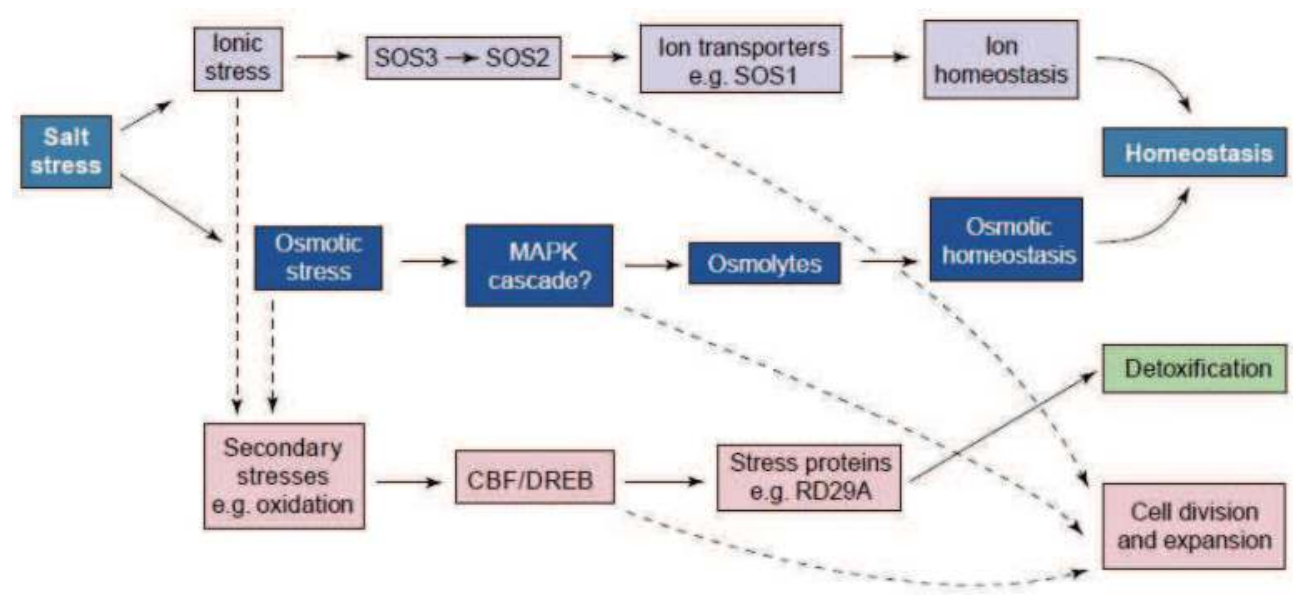

Fig. 4. Three avenues of salt tolerance in plants (after Zhu, 2001). 


\begin{tabular}{|c|c|}
\hline Functionality class & Possible role in stress \\
\hline Signalling molecules & Stress signal transduction and gene expression \\
\hline $\begin{array}{l}\text { Transcriptional and } \\
\text { post-transcriptional } \\
\text { machinery }\end{array}$ & $\begin{array}{l}\text { Transcriptional regulation of stress gene } \\
\text { expression, transcript stability, turnover, } \\
\text { processing }\end{array}$ \\
\hline $\begin{array}{l}\text { Translational } \\
\text { machinery }\end{array}$ & $\begin{array}{l}\text { Stress-regulated protein translation, selective } \\
\text { translation, transport, localization }\end{array}$ \\
\hline Protein folding & $\begin{array}{l}\text { Maintenance of protein structures, protein } \\
\text { folding, preventing protein denaturation, Protein } \\
\text { sorting, targeting }\end{array}$ \\
\hline Protein turnover & $\begin{array}{l}\text { Regulation of protein metabolism, targeted } \\
\text { protein degradation in response to stress }\end{array}$ \\
\hline Osmoprotectants & $\begin{array}{l}\text { Osmotic adjustment, protection of cellular } \\
\text { structures and macromolecules }\end{array}$ \\
\hline Transport protein & $\begin{array}{l}\text { Ion homeostasis during stress, } \\
\text { compartmentalization of solutes and amino acids }\end{array}$ \\
\hline
\end{tabular}

References

Cardinale et al. 2002; Pardo et al. 1998; Saijo et al. 2000;

Ulm et al. 2002

Cooper et al. 2003; Lee et al. 2001; Park et al. 2001;

Sanan-Mishra et al. 2005

Wood et al. 2000; Wood and Oliver 1999

Sun et al. 2001

Maintenance of protein structures, protein sorting, targeting

Regulation of protein metabolism, targeted

Osmotic adjustment, protection of cellular compartmentalization of solutes and amino acids

ROS scavengers, cell death, senescence and ageing

Metal-binding proteins

Photosynthesis

Defense-related proteins

Hormone-related proteins

General metabolism

Detoxification of free oxygen radicals, cell death, hypersensitive response

Affecting cellular metabolism, metal ion homeostasis, acting as cofactors for critical reactions, signaling, metal toxicity, secondary stress responses, oxidative stress

Regulation of photosynthesis

Protection against biotic stress including viral, bacterial and fungal infestation

Hormonal homeostasis and gene expression
Khedr et al. 2003; Moon et al. 2004

Nomura et al. 1998;

Tarczynski et al. 1993

Apse et al. 1999; Gisbert et al. 2000; Shi et al. 2000;

Zhang and Blumwald 2001;

Zhang et al. 2001a

Reddy and Sopory 1999;

Roxas et al. 1997

Kawasaki et al. 2001; Sahi et al. 2003

Overall cellular function, housekeeping metabolic pathways carbohydrate, fatty acid and protein synthesis and modifications membrane fluidity, nitrogen metabolism, carbon and nitrogen fixation
Kawasaki et al. 2001; Sahi et al. 2003

Cheong et al. 2002;

Dombrowski 2003;

Reymond et al. 2000
Kalifa et al. 2004

Hoshida et al. 2000; Jeong et al. 2002

\section{Table 1. Major categories of genes/proteins related to salt-stress responses/tolerances in} plants (After Sahi et al. 2006). 
The mitogen-activated protein kinases (MAP kinases), a specific class of serine/threonine protein kinases, play a central role in the transduction of various extra- and intracellular signals for cell division and stress responses in plants. Most of the abiotic stresses; salinity, cold, drought and oxidative stress can induce defence responses in plants through MAP kinase pathways such as osmoregulation, cell growth and differentiation (Mishra et al., 2006; Pitzschke et al., 2009). AtMKK3, AtMPK1, and AtMPK2 genes induced by ABA signalling amplified through MAP kinase-1 or MAP kinase-2 might increase salt tolerance in Arabidopsis (Hwa \& Yang, 2008). Similarly, expression of active MKK9 protein enhanced salt tolerance and its loss increased sensitivity of transgenic Arabidopsis seedlings, emphasizing the significant role of MKK9 in salt stress response (Xu et al., 2008b). Reactive oxygen species (ROS) scavengers such as peroxidases and glutathione are known to play a significant role in plant salt tolerance by reducing oxidative damage. For instance, in wild $B$. napus, glutathione synthesis was induced during salt stress, suggesting a possible protective mechanism against salt-induced oxidative damage (Ruiz \& Blumwald, 2002).

In another study, genetic manipulation of carotenoid biosynthesis through over-expression of phytoene synthase gene SePSY in transgenic Arabidopsis increased the photosynthesis rate from $92 \%$ to $132 \%$ under $100 \mathrm{mM} \mathrm{NaCl}$ stress. The transgenic plants also displayed higher activities of superoxide dismutase (SOD) and peroxidase (POD) and lower concentrations of $\mathrm{H}_{2} \mathrm{O}_{2}$ and malondialdehyde (MDA) than the wild plants (Han et al. 2008). Therefore, it is important to understand the genetics of detoxification of free oxygen radicals in order to enhance crop salt tolerance.

\subsection{Methods for improving crop salinity tolerance}

Several methods such as germplasm selection, marker assisted selection, transcriptional profiling, metabolomics, proteomics and transgenics have been successfully used for crop salinity improvement. This chapter will only discuss gene expression analysis for salinity tolerance with a main focus on microarrays.

\subsubsection{Gene expression profiling for crop improvement}

Messenger RNAs that are differentially transcribed between tolerant and sensitive genotypes under a particular stress may be targets for selection for future crop improvement. However, the expression of genes involved in stress responses is highly affected by the environment in which they are located, and thus care must be taken to accurately represent the stress environment conditions when seeking differentially transcribed gene responses. The responses may also differ among plant growth stages and among genotypes (Ashraf \& McNeilly, 2004; Munns, 2005; Munns \& Tester, 2008).

In order to determine key genes that are differentially transcribed for metabolic regulation under stress environments and among genotypes, several techniques have been developed. These rapidly provide gene-specific or genome wide expression patterns with high accuracy through biological and technical replication (Kuhn, 2001). Moreover, the information generated can be integrated within functional genomic processes to aid in understanding relationships between gene expressions and observed phenotypes.

\subsubsection{Types of gene expression techniques}

The last decade has produced several dynamic transcriptional technologies for measuring and interpreting single and multiple gene expressions. These have facilitated the analysis of mRNA 
from selected cells/tissues to generate multi-dimensional measurements of differentially expressed genes. Techniques that assess gene expression are grouped into two categories; open and closed systems, based on their architecture. The open system techniques such as AFLP (Amplified Fragment Length Polymorphism), SAGE (Serial Analysis of Gene Expression), MPSS (Massively Parallel Signature Sequencing), and Real-time RT-PCR can permit the discovery of novel genes; however they might not cover the whole genome (Cheng et al., 2008; Drea et al., 2009; Nakano et al., 2006; Sreenivasulu et al., 2010). On the other hand, closed system techniques such as microarrays rely on already annotated information; therefore they can be used to study several thousand genes from a single experiment (Lee et al., 2005; Seki et al., 2002). Due to the flexibility of microarrays to permit the study of multiple stress situations such as salinity, drought and cold in a single experiment, this technique has become a method of choice for many for assessing differential genes expression studies in molecular biology (Dai et al., 2007; Nakashima et al., 2009; Seki et al., 2002).

\subsubsection{Microarray analysis for salt tolerance}

Microarrays utilize the preferential binding of complementary single-stranded nucleic acid sequences. Instead of working on individual genes, the aim of a microarray experiments is to examine the profiles of expression of thousands of genes in a single experiment. Microarrays have been extensively used to study global gene expression profiling of plant responses to abiotic and biotic stresses. Studies on gene expression for abiotic stress include; salinity, drought and cold tolerance in Arabidopsis (Do-Young et al., 2010; Lee et al., 2005; Seki et al., 2002; Seki et al., 2010; Zhenxian et al., 2010), rice (Huang et al., 2008; Walia et al., 2009), wheat (Huang et al., 2008; Kawaura et al., 2008), B. napus (Dalal et al., 2009).

Several types of microarray platforms are available for gene expression studies: those that are spotted with known sequences comprised of cDNA or oligonucleotides, and those manufactured by Agilent and Affymetrix using GeneChip ${ }^{\circledR}$ technologies, which involve synthesis of oligonucleotides directly onto the microarray support. The cDNA microarray is a fabrication of spotted PCR products resulting from direct amplification of genomic DNA by using ESTs or gene specific primers (Alba et al., 2004; Scott et al., 2009). A number of cDNA microarrays have been developed for a variety of plant species such as Arabidopsis, rice, maize, petunia and lima bean (Vij \& Tyagi, 2007). These have been used to study gene regulation at different developmental stages and in response to both abiotic and biotic stresses. Seki et al., (2002) developed a full length cDNA microarray in Arabidopsis to identify genes transcribed in response to cold, drought and salinity, to examine differences in cross-talk between signalling cascades. Currently there are no specific EST-enriched or cDNA gene libraries from $B$. juncea in response to the abiotic stresses of high salinity, alkalinity and/or boron. However, limited information is reported for genes involved in stress tolerance in the Brassicaceae. For example, the cDNAs of the BjDHN2 and BjDHN3 genes from $B$. juncea, a novel subclass of dehydrin genes conferred salt and freezing tolerance in transgenic yeast (Xu et al., 2008a). Similarly, Wang et al. (2003) cloned a new $\mathrm{Na}^{+} / \mathrm{H}^{+}$vacuolar antiporter gene from $B$. napus using a full-length cDNA. The designated vacuolar antiporter gene BnNHX1 was found to be salt-inducible and its transcript level was abundant after 24 hours treatment with $200 \mathrm{mM}$ sodium chloride shock treatment.

\section{Alkalinity}

Alkaline soils are usually categorized by low availability of plant nutrients, high concentrations of $\mathrm{HCO}_{3}{ }^{-}, \mathrm{CO}_{3}{ }^{2-}$ and high $\mathrm{pH}$ (Marschner, 1995; Misra \& Tyler, 1999). By 
definition alkalinity is the concentration of soluble alkalis with the ability to neutralize acids (Bailey 1996). Bicarbonate $\left(\mathrm{HCO}_{3}{ }^{-}\right)$and carbonate $\left(\mathrm{CO}_{3}{ }^{2-}\right)$ are the principal contributors to alkalinity, whereas hydroxide, borate, ammonia, organic bases, phosphates, and silicates are considered minor contributors (Petersen, 1996). Although alkaline soils have high $\mathrm{pH}$ (more $\mathrm{OH}^{-}$than $\mathrm{H}^{+}$), the $\mathrm{OH}^{-}$ions contribute to alkalinity only at $>\mathrm{pH} 11$. Below this $\mathrm{pH}$, alkalinity is mainly caused by $\mathrm{HCO}_{3}^{-}$and $\mathrm{CO}_{3}{ }^{2-}$ ions. Hence, the predominant form of carbonates is determined by the soil $\mathrm{pH}$ (Whipker et al., 1996). The carbonate system consists mostly of $\mathrm{HCO}_{3}{ }^{-}$at $\mathrm{pH} 8.34$. As $\mathrm{pH}$ increases due to the availability of atmospheric $\mathrm{CO}_{2}$ in the system, the proportion of $\mathrm{CO}_{3}{ }^{2-}$ increases and $\mathrm{HCO}_{3}{ }^{-}$declines (Figure 5; Lindsay, 1979). Hence crop growth is mainly inhibited by $\mathrm{HCO}_{3}{ }^{-}$and $\mathrm{CO}_{3}{ }^{2-}$ ions rather than $\mathrm{OH}^{-}$ions in alkaline soils. This has been demonstrated by growing maize plants in solution at $\mathrm{pH} 8.0$ with the buffer HEPES, without $\mathrm{HCO}_{3}{ }^{-}$. The high $\mathrm{pH}$ due to HEPES buffer did not cause any reduction of root and shoot elongation (Lee \& Woolhouse, 1969; Romera et al., 1992).

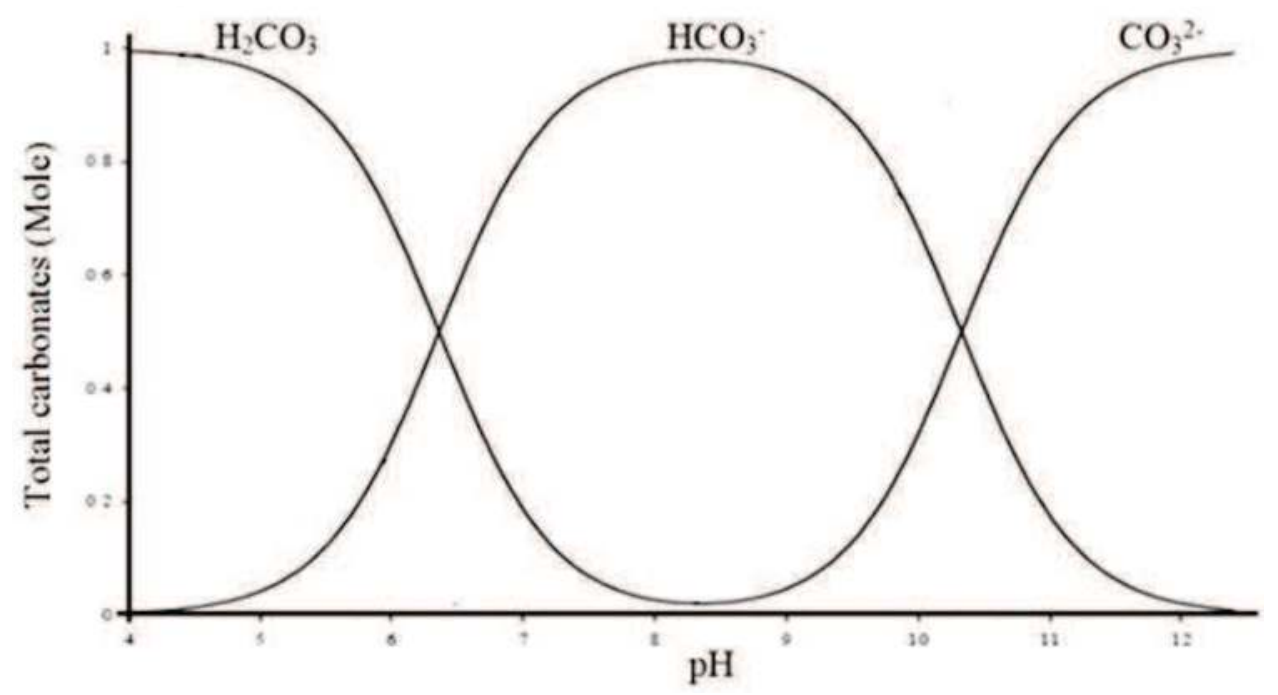

Fig. 5. Three carbonate species at different $\mathrm{pH}$ (after Lindsay, 1979)

\subsection{Nutrient availability in alkaline soils}

Several essential micro nutrients such as $\mathrm{Fe}, \mathrm{Zn}$ and $\mathrm{Mn}$ become less available to plants under alkaline stress (Guardia \& Alcántara, 2002; Valdez-Aguilar \& Reed, 2008; 2010). Nitrogen and Phosphorus deficiencies are also caused by alkalinity. Bicarbonate can significantly decrease Fe uptake, accumulation and/or raise internal Fe precipitation (Fernández-Falcón et al., 1986; Bertoni et al., 1992; Alhendawi et al., 1997; Norvell \& Adams, 2006). The alkalinization of root tissues due to $\mathrm{HCO}_{3}{ }^{-}$can either inhibit $\mathrm{Fe}$ acquisition or cause Fe to precipitate in the root apoplasm (Fernández Falcón et al., 1986; Bertoni et al., 1992 and Römheld, 2000). Alhendawi et al. (1997) found that $\mathrm{Fe}$ concentrations in roots of barley, maize and sorghum were significantly reduced when grown in solutions containing 5 to $20 \mathrm{mM} \mathrm{HCO}_{3}{ }^{-}$.

Iron $(\mathrm{Fe})$ chlorosis is a major problem for crops grown in calcareous soils. Soluble bicarbonate has been documented as a contributor to iron (Fe) deficiency and lime-induced chlorosis of crops growing on calcareous soils (Wadleigh \& Brown, 1952; Brown, 1978; 
Coulombe et al., 1984; Marschner, 1995). In bicarbonate buffer, the $\mathrm{pH}$ is in the alkaline range and reduces the uptake or utilization of $\mathrm{Fe}$, leading to deficiency that results in leaf chlorosis (Chaney et al., 1992; Parker \& Norvell, 1999; Brand et al., 2002; Lucena, 2000 Norvell \& Adams, 2006; Valdez-Aguilar \& Reed, 2008; 2010).

Besides $\mathrm{Fe}$, other nutrients that become deficient at high $\mathrm{pH}$ include calcium $(\mathrm{Ca})$, copper $(\mathrm{Cu})$, phosphorus $(\mathrm{P})$, and zinc $(\mathrm{Zn})$ (Figure 6; Al-Karaki \& Al-Omoush, 2002; Chaves et al., 2006; Naidu \& Rengasamy, 1993; Valdez-Aguilar \& Reed, 2010). Plant response to alkalinity for nutrient uptake varies from crop to crop. For example, Solaiman et al. (2007) found that canola genotypes maintained higher uptake of $\mathrm{P}$ and accumulated greater biomass on alkaline soils compared to wheat genotypes. The better growth and $\mathrm{P}$ content of the canola genotypes compared to the wheat genotypes was due to the greater root length, leading to exploitation of greater soil volume. However on alkaline soils, $\mathrm{P}$ may be rapidly fixed into non plant-labile pools, by precipitation of Ca-P compounds not accessible to plant roots (Bertrand et al., 2006). In a recent study, Valdez-Aguilar \& Reed (2008) found that N, K, Ca, $\mathrm{Mg}$ and Fe concentrations were higher in roots than shoots of $\mathrm{HCO}_{3}{ }^{-}$treated tomato plants.

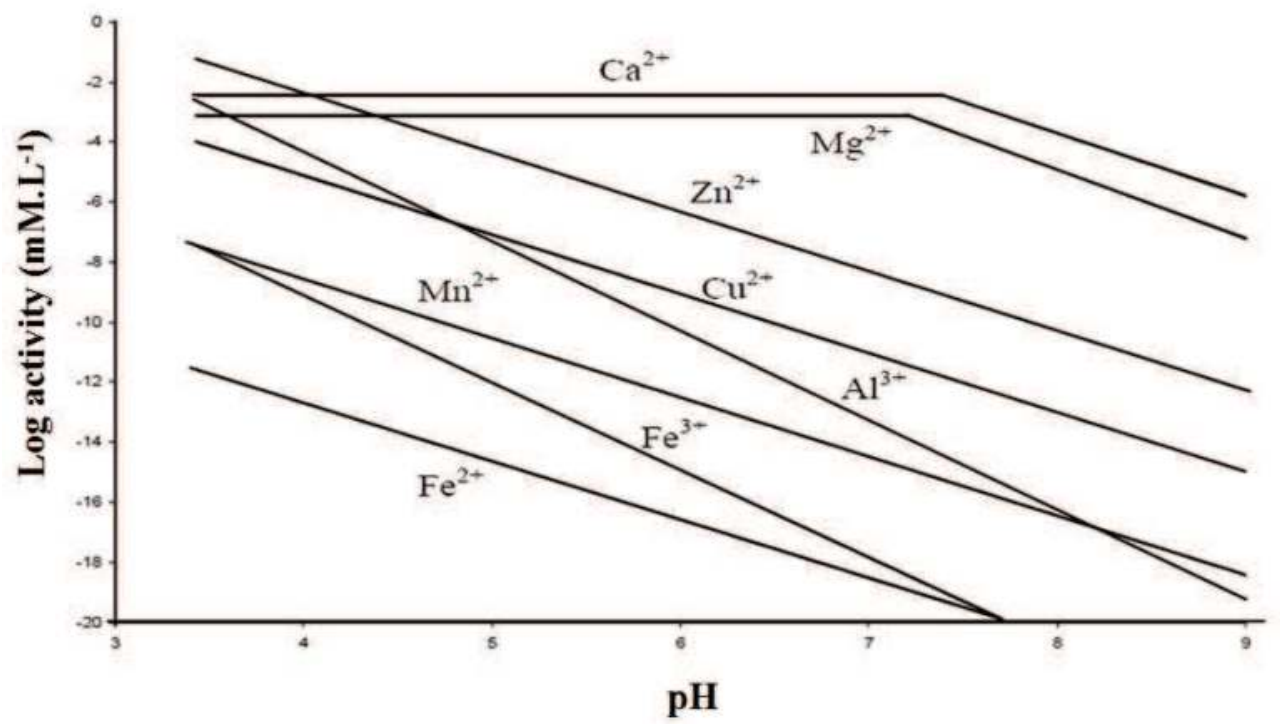

Fig. 6. Effect of increasing $\mathrm{pH}$ on availability of various nutrients (after Lindsay 1979).

\subsection{Effect of alkalinity on plant growth}

Plant growth is significantly reduced by alkaline stress mainly contributed by decreased shoot growth with smaller leaves and reduced leaf area as well as reduced root growth and elongation (Pearce et al., 1999). Plants show minor to severe stunting of growth depending on $\mathrm{HCO}_{3}{ }^{-}$concentration in the soil solution. Growth of many commercial crops such as bean (Valdez-Aguilar \& Reed, 2008; 2010), cucumber (Rouphael et al., 2010), wheat (Yang et al., 2008c), sorghum, maize barley (Alhendawi et al., 1997; Yang et al., 2009), soybean (Rogovska et al. ,2009), sunflower (Alcántara et al., 1988; Shi \& Sheng, 2005), tomato (Bailey \& Hammer, 1986; Bialczyk \& Lechowsk, 1995; Bialczyk et al., 2004; Navarro et al., 2000), pea (Zribi \& Gharsalli, 2002), and rice (Hajiboland et al., 2005; Yang et al., 1994) are reported to be 
considerably affected by $\mathrm{HCO}_{3}{ }^{-}$. Toxic concentrations of bicarbonate can diminish leaf area, leaf length and leaf width, consequently shoot biomass is decreased. This may be due to decreased photosynthetic rate and stomatal conductance in bicarbonate-induced leaf chlorosis (Bie et al., 2004). The reduction in photosynthetic rate is due to impaired chlorophyll synthesis as a result of low translocation of Fe (Bavaresco et al., 1999).

Increasing concentrations of bicarbonate inhibit root growth, which varies with crop species and bicarbonate concentration. Higher $\mathrm{HCO}_{3}{ }^{-}$concentrations can inhibit root respiration and may result in reduced root growth (Bingham \& Stevenson, 1993; Alhendawi et al., 1997). This inhibitory effect may also be related to high accumulation and compartmentation of organic acids such as malate and citrate in root cells (Lee \& Woolhouse, 1969; Yang et al., 1994). A bicarbonate-induced build-up of surplus organic acids, particularly malate, in the elongation zone appeared to be related to inhibition of root elongation by bicarbonate in calcifuge plant species (Lee \& Woolhouse, 1969). Abscisic acid (ABA), an important stress-induced hormone, is produced in the roots and leaves, transferred from the roots to the leaves in the xylem and from the leaves back to the roots in the phloem (Wolf et al., 1990). Excessive ABA inhibits shoot growth, but increases root growth especially under stress conditions, thus sustaining root growth in drying soils (Saab et al., 1990). In alkaline soils, ABA may leak from the roots to the soil despite being released into the xylem, thereby causing root inhibition as water becomes less available (Daeter et al., 1993; Slovik et al., 1995). Crop species such as corn that can retain root $\mathrm{ABA}$ in the face of its tendency to leach into the more alkaline compartment are better able to tolerate these harmful stresses (Degenhardt, 2000).

Crops such as maize, sorghum, and barley have also shown depressed root growth at elevated levels of bicarbonate stress (Alhendawi et al,. 1997). Whereas some other crops such as sugar beet, sunflower, pea, and rice are considered better able to tolerate bicarbonate stress (Alcántara et al., 1988; Campbell \& Nishio, 2000; Yang et al., 1994; Zribi \& Gharsalli, 2002). For instance, root thickness, and lateral root production of sugar beet were increased after three days of Fe deficiency and $\mathrm{HCO}_{3}{ }^{-}$treatments (Campbell \& Nishio, 2000).

\subsection{Molecular responses to alkalinity stress}

Most of the studies to date have focussed on the physiological impacts of alkalinity stress. Recently, Yang et al., (2008) constitutively expressed the high affinity bicarbonate transporter gene "IctB" from Cyanobacterium in rice. Under low $\mathrm{CO}_{2}$ or alkaline water conditions, cyanobacteria use bicarbonate transporters to pump in bicarbonate as a major carbon source to survive under unfavourable growth conditions. All transgenic rice lines expressing the transporter exhibited enhanced photosynthetic capacity, growth and grain yield (Yang et al., 2008).

As previously mentioned, Fe deficiency is one of the predicted outcomes of alkalinity, therefore an understanding of how plants acquire this ion under stress is needed. Plants have developed two discrete iron uptake strategies by the roots (Marschner et al., 1987). For most plants, including dicots and non-graminaceous monocots, ferrous ion Fe (II) transport from soil into root cells takes place via a transporter after reduction from ferric ion Fe (III) on the plasma membrane (Eide et al., 1996; Robinson et al., 1999; strategy I). However some graminaceous plants synthesise and release iron-chelating phytosiderophores, hence have a specific iron uptake system, the Fe (III)-phytosiderophore complex (Romheld \& Marschner, 1986; strategy II).

Barley is the most tolerant species to iron deficiency among the graminaceous plants and Murata et al. (2006) identified an iron-phytosiderophore transporter "HvYS1" gene which has 
72.7\% similarity with ZmYS1, the first protein identified as an iron(III)-phytosiderophore transporter in maize. The expression of this gene is linked to iron deficient conditions and is expressed in the epidermal root cells. The localization and substrate specificity of HvYS1 is different from those of ZmYS1, indicating that HvYS1 is a specific transporter involved in primary iron acquisition from soil in barley roots (Namba \& Murata, 2010).

\section{Conclusions}

Further research is required to determine the key genes and molecular pathways that underpin the best tolerance responses of our elite crop genotypes to the common abiotic soil constraints including salinity and alkalinity. Once uncovered and assessed to be stably expressed under varying background environments and genomes, these genetic mechanisms may become central to future tolerance breeding programs through advanced selection methods. Also, full characterisation of shared molecular mechanisms to multiple stresses may uncover strategic selection tools for breeding cultivars that are tolerant to stresses that occur simultaneously.

For example, when alkalinity is combined with salinity in the same soil environment, the negative impact on plant growth is significantly increased (Li et al., 2010; Shi \& Sheng, 2005). Saline soils containing $\mathrm{CO}_{3}{ }^{2-}$ and/or $\mathrm{HCO}_{3}{ }^{-}$can cause injury to plants through high salts as well as through carbonates and bicarbonate (Shi \& Sheng, 2005). The combined stress (alkaline salinity) leads to Na toxicity due to high concentrations of salt and deficiencies of $\mathrm{Fe}$ and $\mathrm{Zn}$. Therefore, future genetic studies and screening for selective breeding should incorporate the interactive nature and impacts of multiple concurrent stresses.

\section{References}

Al-Karaki GN, Al-Omoush M (2002) Wheat response to phosphogypsum and mycorrhizal fungi in alkaline soil. Journal of Plant Nutrition 25, 873-883.

Alba R, Fei Z, Payton P, Liu Y, Moore SL, Debbie P, Cohn J, D'Ascenzo M, Gordon JS, Rose JKC (2004) ESTs, cDNA microarrays, and gene expression profiling: tools for dissecting plant physiology and development. The Plant Journal 39, 697-714.

Alcántara E, Romera FJ, de la Guardia MD (1988) Genotypic differences in bicarbonateinduced iron chlorosis in sunflower. Journal of Plant Nutrition 11, 65-75.

Alhendawi RA, Römheld V, Kirkby EA, Marschner H (1997) Influence of increasing bicarbonate concentrations on plant growth, organic acid accumulation in roots and iron uptake by barley, sorghum and maize. Journal of Plant Nutrition. 20, 1731-1753.

Apse MP, Aharon GS, Snedden WA, Blumwald E (1999) Salt tolerance conferred by overexpression of a vacuolar $\mathrm{Na}^{+} / \mathrm{H}^{+}$antiport in Arabidopsis. Science 285, 1256-1258.

Apse MP, Sottosanto JB, Blumwald E (2003) Vacuolar cation $/ \mathrm{H}^{+}$exchange, ion homeostasis, and leaf development are altered in a T-DNA insertional mutant of AtNHX1, the Arabidopsis vacuolar $\mathrm{Na}^{+} / \mathrm{H}^{+}$antiporter. The Plant Journal 36, 229 - 239.

Ashraf M, Akram NA (2009) Improving salinity tolerance of plants through conventional breeding and genetic engineering: An analytical comparison. Biotechnology Advances 27, 744-752.

Ashraf M, McNeilly T (2004) Salinity Tolerance in Brassica Oilseeds. Critical Reviews in Plant Sciences 23, 157-174. 
Ashraf M, Nazir N, McNeilly T (2001) Comparative salt tolerance of amphidiploid and diploid Brassica species. Plant Science 160, 683-689.

Bailey DA (1996) Alkalinity and acidification. P. 69-91. In: Reed, D.Wm. (ed.). Water, media and nutrition. Ball Publishing, Batavia, IL.

Bailey DA, Hammer PA (1986) Growth and nutritional status of petunia and tomato seedlings with acidified water. Horticulture Science 21, 423-425.

Bavaresco L, Giachino E, Colla R (1999) Iron chlorosis paradox in grapevine. Journal of Plant Nutrition 22, 1589-1597.

Benke K, Qiang W, Yujuan G, Zhenfei S, Ningjing L (2010) Sequence of Ammopiptanthus mongolicus $\mathrm{Na}^{+} / \mathrm{H}^{+}$antiporter $\mathrm{NHX1}$ regulating plant resistance to salt and drought stresses Faming Zhuanli Shenqing Gongkai Shuomingshu CN 101701037 A 20100505.

Bertoni GM, Pissaloux A, Morad P, Sayag DR (1992) Bicarbonate-pH relationship with iron chlorosis in white lupine. Journal of Plant Nutrition 15, 1509-1518.

Bertrand I, McLaughlin MJ, Holloway RE, Armstrong RD, McBeath T (2006) Changes in P Bioavailability Induced by the Application of Liquid and Powder Sources of $\mathrm{P}, \mathrm{N}$ and Zn Fertilizers in Alkaline Soils. Nutrient Cycling in Agroecosystems 74, 27-40.

Bialczyk J, Lechowski Z (1995) Chemical composition of xylem sap of tomato grown on bicarbonate containing medium. Journal of Plant Nutrition 18, 2005-2021.

Bialczyk J, Lechowski Z, Dziga D (2004) Composition of the xylem sap of tomato seedlings cultivated on media with $\mathrm{HCO}_{3}$ - and nitrogen source as $\mathrm{NO}_{3}^{-}$or $\mathrm{NH}_{4}{ }^{+}$. Plant and Soil 263, 265-272.

Bie Z, Ito T, Shinohara Y (2004) Effects of sodium sulfate and sodium bicarbonate on the growth, gas exchange and mineral composition of lettuce. Scientia Horticulturae 99, 215-224.

Bingham IJ, Stevenson EA (1993) Control of root growth: effects of carbohydrates on the extension, branching, and rate of respiration of different fractions of wheat roots. Physiologia Plantarum. 88, 149-158.

Blumwald E, Aharon GS, Apse MP (2000) Sodium transport in plant cells. Biochimica et Biophysica Acta 1465, 140-151.

Blumwald E, Grover A, Good AG (2004) Breeding for abiotic stress resistance: Challenges and opportunities. "New directions for a diverse planet". Proceedings of the 4th International Crop Science Congress 26 Sep-1 Oct 2004, Brisbane, Australia.

Brand J, Tang C, Rathjen AJ (2002) Screening rough-seeded lupins (Lupinus pilosus Murr. and Lupinus atlanticus Glads.) for tolerance to calcareous soils. Plant and Soil 245, 261-275.

Braun Y, Hassidim M, Lerner HR, Reinhold L (1986) Studies on $\mathrm{H}^{+}$-Translocating ATPases in Plants of Varying Resistance to Salinity: I. Salinity during Growth Modulates the Proton Pump in the Halophyte Atriplex nummularia. Plant Physiology 81, 1050-1056.

Brown JC (1978) Mechanism of iron uptake by plants. Plant, Cell \& Environment 1, 249-257.

Campbell SA, Nishio JN (2000) Iron deficiency studies of sugar beet using an improved sodium bicarbonate-buffered hydroponic growth system. Journal of Plant Nutrition. 23, 741-757.

Cardinale F, Meskiene I, Ouaked F, Hirt H (2002) Convergence and divergence of stressinduced mitogen-activated protein kinase signaling pathways at the level of two distinct mitogen-activated protein kinase kinases. The Plant Cell Online 14, 703-711.

Casas AM, Bressan RA, Hasegawa PM (1991) Cell growth and water relations of the halophyte, Atriplex nummularia L., in response to NaCl. Plant Cell Reports 10, 81-84. 
Casas AM, Nelson DE, Raghothama KG, D'Urzo MP, Singh NK, Bressan RA, Hasegawa PM (1992) Expression of osmotin-like genes in the halophyte Atriplex nummularia $L$. Plant Physiology and Biochemistry 99, 329-337.

Chaney R, Coulombe B, Bell P, Angle J (1992) Detailed method to screen dicot cultivars for resistance to Fe-chlorosis using FeDTPA and bicarbonate in nutrient solutions. Journal of Plant Nutrition 15, 2063-2083.

Chaves LA, Garcia J, Jimenez S, Lao MT (2006) Influence of the modification of nutritional parameters in Aglaonema commutatum: $\mathrm{K}^{+}, \mathrm{Ca}^{2+}, \mathrm{Mg}^{2+}$ and $\mathrm{Na}^{+}$. Communications in Soil Science and Plant Analysis 37, 2927-2937.

Chen T, Murata N (2002) Enhancement of tolerance of abiotic stress by metabolic engineering of betaines and other compatible solutes. Current Opinion in Plant Biology 5, 250-257.

Cheng L, Huan S, Sheng Y, Hua X, Shu Q, Song S, Jing X (2008) GMCHI, cloned from soybean [Glycine max (L.) Meer.], enhances survival in transgenic Arabidopsis under abiotic stress Plant Cell Reports 28, 145-153.

Cheong Y, Chang H, Gupta R, Wang X, Zhu T, Luan S (2002) Transcriptional profiling reveals novel interactions between wounding, pathogen abiotic stress and hormonal responses in Arabidopsis. Plant Physiology 129, 661-677.

Cooper B, Clarke JD, Budworth P, Kreps J, Hutchison D, Park S, Guimil S, Dunn M, Luginbühl P, Ellero C (2003) A network of rice genes associated with stress response and seed development. Proceedings of the National Academy of Sciences of the United States of America 100, 4945-4950.

Coulombe BA, Chaney RL, Wiebold WJ (1984) Use of bicarbonate in screening soybeans for resistance to iron chlorosis. Journal of Plant Nutrition 7, 411-425.

Daeter W, Slovik S, Hartung W (1993) The pH gradients in the root system and the abscisic acid concentration in xylem and apoplastic saps. Philosophical Transactions: Biological Sciences 341, 49-56.

Dai X, Xu Y, Ma Q, Xu W, Wang T, Xue Y, Chong K (2007) Overexpression of an R1R2R3 MYB Gene, OsMYB3R-2, Increases Tolerance to Freezing, Drought, and Salt Stress in Transgenic Arabidopsis. Plant Physiology 143, 1739-1751.

Dalal M, Tayal D, Chinnusamy V, Bansal KC (2009) Abiotic stress and ABA-inducible Group 4 LEA from Brassica napus plays a key role in salt and drought tolerance. Journal of Biotechnology 139, 137-145.

Degenhardt B (2000) Effect of alkaline and saline substrates on ABA contents, distribution and transport in plant roots. Plant and Soil 225, 83-94.

Do-Young K, Jun-Young J, Santiago A, Enrico M, Youngsook L (2010) Overexpression of AtABCG36 improves drought and salt stress resistance in Arabidopsis Physiologia Plantarum 139, 170-180.

Dombrowski JE (2003) Salt stress activation of wound-related genes in tomato plants. Plant Physiology 132, 2098-107.

Drea S, Derbyshire P, Koumproglou R, Dolan L, Doonan JH, Shaw P (2009) In situ Analysis of Gene Expression in Plants. Methods in Molecular Biology, Plant Genomics 513, 229-242.

Eide D, Broderius M, Fett J, Guerinot ML (1996) A novel iron-regulated metal transporter from plants identified by functional expression in yeast. Proceedings of the National Academy of Sciences of the United States of America 93, 5624-5628.

FAO (2009) FAO Land and Plant Nutrition Management Service http://www.fao.org/ag/agl/agll/spush 
FAO (2000) Global network on integrated soil management for sustainable use of saltaffected soils. FAO Land and Plant Nutrition Management Service, Rome, Italy www.fao.org./ag/agl/agll/spush/topic2.htm\#australia

Fernández-Falcón M, González CEA, García V, Báez J (1986) The effect of chloride and bicarbonate levels in irrigation water on nutrient content, production and quality of cut roses 'Mercedes'. Scientia Horticulturae 29, 373-385.

Fernandez P, Di Rienzo J, Fernandez L, Hopp HE, Paniego N, Heinz RA (2008) Transcriptomic identification of candidate genes involved in sunflower responses to chilling and salt stresses based on cDNA microarray analysis. BMC Plant Biology 8, 11.

Flowers TJ, Colmer TD (2008) Salinity tolerance in halophytes. New Phytologist 179, 945-963.

Gisbert C, Rus AM, Bolar n MC, López-Coronado JM, Arrillaga I, Montesinos C, Caro M, Serrano R, Moreno V (2000) The yeast HAL1 gene improves salt tolerance of transgenic tomato. Plant Physiology 123, 393-402.

Guardia MDDl, Alcántara. E (2002) Bicarbonate and low iron level increase root to total plant weight ratio in olive and peach rootstock. Journal of Plant Nutrition 25, 1021-1032.

Hajiboland R, Yang X, Römheld V, Neumann G (2005) Effect of bicarbonate on elongation and distribution of organic acids in root and root zone of Zn-efficient and Zninefficient rice (Oryza sativa L.) genotypes. Environmental and Experimental Botany 54, 163-173.

Han H, Li Y, Zhou S (2008) Overexpression of phytoene synthase gene from Salicornia europaea alters response to reactive oxygen species under salt stress in transgenic Arabidopsis Biotechnology Letters 30, 1501-1507.

Hasegawa PM, Bressan RA (2000) Plant cellular and molecular responses to high salinity. Annual Review of Plant Physiology and Plant Molecular Biology 51, 463-99.

Hassidim M, Braun Y, Lerner HR, Reinhold L (1990) $\mathrm{Na}^{+} / \mathrm{H}^{+}$and $\mathrm{K}^{+} / \mathrm{H}^{+}$antiport in root membrane vesicles isolated from the halophyte Atriplex and the glycophyte cotton. Plant Physiology 94, 1795-1801.

Hernández A, Jiang X, Cubero B, Nieto PM, Bressan RA, Hasegawa PM, Pardo JM (2009) Mutants of the Arabidopsis thaliana Cation/ $\mathrm{H}^{+}$Antiporter AtNHX1 Conferring Increased Salt Tolerance in Yeast. The Journal of Biological Chemistry 284, 14276-14285.

Hoshida H, Tanaka Y, Hibino T, Hayashi Y, Tanaka A, Takabe T (2000) Enhanced tolerance to salt stress in transgenic rice that overexpresses chloroplast glutamine synthetase. Plant Molecular Biology 43, 103-111.

$\mathrm{Hu}$ Y, Schmidhalter U (1998) Spatial distributions and net deposition rates of mineral elements in the elongating wheat (Triticum aestivum L.) leaf under saline soil conditions. Planta 204, 212-219.

$\mathrm{Hu}$ Y, Schmidhalter U (2005) Drought and salinity: A comparison of their effects on mineral nutrition of plants. Journal of Plant Nutrition and Soil Science 168, 541-549.

Huang J, Redman R (1995) Physiological responses of canola and wild mustard to salinity and contrasting calcium supply. Journal of Plant Nutrition 18, 1931-1949.

Huang S, Spielmeyer W, Lagudah ES, Munns R (2008) Comparative mapping of HKT genes in wheat, barley, and rice, key determinants of $\mathrm{Na}^{+}$transport, and salt tolerance. Journal of Experimental Botany 59, 927-937.

Husain S, von-Caemmerer S, Munns R (2004) Control of salt transport from roots to shoots of wheat in saline soil. Functional Plant Biology 31, 1115-1126.

Hwa C-M, Yang X-C (2008) The AtMKK3 pathway mediates ABA and salt signaling in Arabidopsis. Acta Physiologiae Plantarum 30, 277-286. 
Incerti M, O'Leary GJ (1990) Rooting depth of wheat in Victorian Mallee. Australian Journal of Experimental Agriculture 30, 817-824.

Jeong MJ, Park SC, Byun MO (2002) Improvement of salt tolerance in transgenic potato plants by glyceraldehyde-3 phosphate dehydrogenase gene transfer. Molecules and Cells 12, 185-189.

Kalifa Y, Gilad A, Konrad Z, Zaccai M, Scolnik PA, Bar-Zvi D (2004) The water-and saltstress-regulated Asr1 (abscisic acid stress ripening) gene encodes a zinc-dependent DNA-binding protein. Biochemical Journal 381, 373-378.

Kawasaki S, Borchert C, Deyholos M, Wang H, Brazille S, Kawai K, Galbraith D, Bohnert H (2001) Gene expression profiles during the initial phase of salt stress in rice. Plant Cell 13, 889-905.

Kawaura K, Mochida K, Ogihara Y (2008) Genome-wide analysis for identification of saltresponsive genes in common wheat. Functional Integrative Genomics 8, 277-286.

Khedr AHA, Abbas MA, Wahid AAA, Quick WP, Abogadallah GM (2003) Proline induces the expression of salt stress responsive proteins and may improve the adaptation of Pancratium maritimum L. to salt stress. Journal of Experimental Botany 54, 2553-2562.

Kuhn E (2001) From library screening to microarray technology, strategies to determine gene expression profiles and to identify differentially regulated genes in plants. Annals of Botany 87, 139-155.

Kumar D (1995) Salt tolerance in oilseed brassicas - present status and future prospects. Plant Breeding Abstracts 65, 1438-1447.

Kumar G, Purty RS, Sharma MP, Singla-Pareek SL, Pareeka A (2009) Physiological responses among Brassica species under salinity stress show strong correlation with transcript abundance for SOS pathway-related genes. Journal of Plant Physiology 166, 507-520.

Lee B-h, Henderson DA, Zhu J-K (2005) The Arabidopsis Cold-Responsive Transcriptome and Its Regulation by ICE1. Plant Cell 17, 3155-3175.

Lee H, Xiong L, Gong Z, Ishitani M, Stevenson B, Zhu JK (2001) The Arabidopsis HOS1 gene negatively regulates cold signal transduction and encodes a RING finger protein that displays cold-regulated nucleo-cytoplasmic partitioning. Genes and Development 15, 912-924.

Lee JA, Woolhouse HW (1969) A comparative study of bicarbonate inhibitions of root growth in calcicole and calcifuge grasses. New Phytologist 68, 1-11.

Li C, Fang B, Yang C, Shi D, Wang D (2009) Effects of various salt-alkaline mixed stresses on the state of mineral elements in nutrient solutions and the growth of alkali resistant halophyte Chloris Virgata. Journal of Plant Nutrition 32, 1137-1147.

Li R, Shi F, Fukuda K (2010) Interactive effects of salt and alkali stresses on seed germination, germination recovery, and seedling growth of a halophyte Spartina alterniflora (Poaceae). South African Journal of Botany 76, 380-387.

Lindsay WL (1979) 'Chemical equilibria in soils.' (The Blackburn Press, Caldwell, NJ: Caldwell, NJ).

Lucena JJ (2000) Effects of bicarbonate, nitrate and other environmental factors on iron deficiency chlorosis. A review. Journal of Plant Nutrition 23, 1591- 1606.

Marschner H (1995) Mineral Nutrition of Higher Plants. 2nd edition. Academic Press, San Diego. pp. 379-396.

Marschner H, Römheld V, Kissel M (1987) Localization of phytosiderophore release and of iron uptake along intact barley roots. Physiologia Plantarum 71, 157-162.

Mishra NS, Tuteja R, Tuteja N (2006) Signaling through MAP kinase networks in plants. Archives of Biochemistry and Biophysics 452, 55-68 
Misra A, Tyler G (1999) Influence of Soil Moisture on Soil Solution Chemistry and Concentrations of Minerals in the Calcicoles Phleum phleoides and Veronica spicata Grown on a Limestone Soil. Annals of Botany 84, 401-410.

Moller IS, Gilliham M, Jha D, Mayo GM, Roy SJ, Coates JC, Haseloff J, Tester M (2009) Shoot $\mathrm{Na}^{+}$Exclusion and Increased Salinity Tolerance Engineered by Cell Type-Specific Alteration of $\mathrm{Na}^{+}$Transport in Arabidopsis. Plant Cell 21, 2163-2178.

Møller IS, Tester M (2007) Salinity tolerance of Arabidopsis: a good model for cereals? Trends in Plant Science 12, 534-540.

Moon J, Parry G, Estelle M (2004) The ubiquitin-proteasome pathway and plant development. The Plant Cell Online 16, 3181-3195.

Munns R (1993) Physiological processes limiting plant growth in saline soils: some dogmas and hypotheses. Plant, Cell and Environment 16, 15-24.

Munns R (2002) Comparative physiology of salt and water stress. Plant, Cell and Environment. 25, 239-250.

Munns R (2005) Genes and salt tolerance: bringing them together. New Phytologist 167, 645-663.

Munns R, James RA (2003) Screening methods for salinity tolerance: a case study with tetraploid wheat. Plant and Soil 253, 201-218.

Munns R, Schachtman DP, Condon AG (1995) The Significance of a Two-Phase Growth Response to Salinity in Wheat and Barley. Functional Plant Biology 22, 561-569.

Munns R, Tester M (2008) Mechanisms of Salinity Tolerance. Annual Review of Plant Biology 59, 651-681.

Murata Y, Ma JF, Yamaji N, Ueno D, Nomoto K, Iwashita T (2006) A specific transporter for iron(III)-phytosiderophore in barley roots. The Plant Journal 46, 563-572.

Naidu R, Rengasamy P (1993) Ion Interactions and Constraints to Plant Nutrition in Australian Sodic Soils. Australian Journal of Soil Research 31, 801-19.

Nakano M, Nobuta K, Vemaraju K, Tej SS, Skogen JW, Meyers BC (2006) Plant MPSS databases: signature-based transcriptional resources for analyses of mRNA and small RNA Nucleic Acids Research 34, D731-D735.

Nakashima K, Ito Y, Yamaguchi-Shinozaki K (2009) Transcriptional regulatory networks in response to abiotic stresses in Arabidopsis and Grasses. Plant Physiology 149, 88-95.

Namba K, Murata Y (2010) Toward mechanistic elucidation of iron acquisition in barley: efficient synthesis of mugineic acids and their transport activities. The Chemical Record 10, 140-150.

Navarro JM, Martınez V, Carvajal M (2000) Ammonium, bicarbonate and calcium effects on tomato plants grown under saline conditions. Plant Science 157 89-96.

Netondo GW, Onyango JC, Beck E (2004) Sorghum and Salinity: I. Response of Growth, Water Relations, and Ion Accumulation to $\mathrm{NaCl}$ Salinity. Crop Science 44, 797-805.

Nomura M, Hibino T, Takabe T, Sugiyama T, Yokota A, Miyake H (1998) Transgenically produced glycinebetaine protects ribulose 1, 5-bisphosphate carboxylase/ oxygenase from inactivation in Synechococcus sp. PCC7942 under salt stress. Plant and Cell Physiology 39, 425-432.

Norvell WA, Adams ML (2006) Screening Soybean Cultivars for Resistance to IronDeficiency Chlorosis in Culture Solutions Containing Magnesium or Sodium Bicarbonate. Journal of Plant Nutrition 29, 1855-1867.

Nuttall JG, Armstrong RD, Connor DJ (2003a) Evaluating physiochemical constraints of Calcarosols on wheat yield in the Victorian southern Mallee. Australian Journal of Agricultural Research 54, 487-497. 
Nuttall JG, Armstrong RD, Connor DJ, Matassa VJ (2003b) Interrelationships between edaphic factors potentially limiting cereal growth on alkaline soils in north-western Victoria. Australian Journal of Soil Research 41, 277-292.

Pardo JM, Reddy MP, Yang S, Maggio A, Huh GH, Matsumoto T, Coca MA, Paino-D’Urzo M, Koiwa H, Yun DJ (1998) Stress signaling through $\mathrm{Ca}^{2+}$ /calmodulin-dependent protein phosphatase calcineurin mediates salt adaptation in plants. Proceedings of the National Academy of Sciences of the United States of America 95, 9681-9686.

Park JM, Park CJ, Lee SB, Ham BK, Shin R, Paek KH (2001) Overexpression of the tobacco Tsi1 gene encoding an EREBP/AP2-type transcription factor enhances resistance against pathogen attack and osmotic stress in tobacco. The Plant Cell Online 13, 1035-1046.

Parker DR, Norvell WA (1999) Advances in solution culture methods for plant mineral nutrition research. Advances in Agronomy 65, 151-213.

Pearce RC, Li Y, Bush. LP (1999) Calcium and bicarbonate effects on the growth and nutrient uptake of burley tobacco seedlings: hydroponic culture. Journal of Plant Nutrition 22, 1069-1078.

Petersen FH (1996) Water testing and interpretation. p. 31-49. In: Reed, D.Wm. (Editor). Water, media and nutrition. Ball Publishing, Batavia, IL.

Pitzschke A, Schikora A, Hirt H (2009) MAPK cascade signalling networks in plant defence. Current Opinion in Plant Biology 12, 421-426.

Popova OV, Yang O, Dietz KJ, Golldack D (2008) Differential transcript regulation in Arabidopsis thaliana and the halotolerant Lobularia maritima indicates genes with potential function in plant salt adaptation. Gene 423, 142-148.

Rawson HM, Long MJ, Munns R (1988) Growth and development in NaCl-treated plants. 1. Leaf $\mathrm{Na}^{+}$and $\mathrm{Cl}^{-}$concentrations do not determine gas exchange of leaf blades of barley. Australian Journal of Plant Physiology 15, 519-527.

Reddy VS, Sopory SK (1999) Glyoxalase I fromBrassica juncea: molecular cloning, regulation and its over expression confer tolerance in transgenic tobacco under stress. The Plant Journal 17, 385-395.

Rengasamy P (2002) Transient salinity and subsoil constraints to dryland farming in Australian sodic soils: an overview. Australian Journal of Experimental Agriculture 42, 351-361.

Rengasamy P (2006) World salinization with emphasis on Australia. Journal of Experimental Botany 57, 1017-1023.

Reymond P, Weber H, Damond M, Farmer EE (2000) Differential gene expression in response to mechanical wounding and insect feeding in Arabidopsis. The Plant Cell Online 12, 707-719.

Robinson NJ, Procter CM, Connolly EL, Guerinot ML (1999) A ferric-chelate reductase for iron uptake from soils. Nature 397, 694-697.

Rogovska NP, Blackmer AM, Tylka GL (2009) Soybean Yield and Soybean Cyst Nematode Densities Related to Soil pH, Soil Carbonate Concentrations, and Alkalinity Stress Index. Agronomy Journal 101, 1019-1026.

Romera FJ, Alcántara E, de la Guardia MD (1992) Effects of bicarbonate, phosphate and high $\mathrm{pH}$ on the reducing capacity of Fe-deficient sunflower and cucumber plants. Journal of Plant Nutrition 15, 1519-1530.

Römheld V, Marschner H (1986) Evidence for a specific uptake system for iron phytosiderophores in roots of grasses. Plant Physiology 80, 175-180.

Römheld V (2000) The chlorosis paradox: Fe inactivation as a secondary event in chlorotic leaves of grapevine. Journal of Plant Nutrition 23, 1629-1643. 
Rouphael Y, Cardarelli M, Di Mattia E, Tullio M, Rea E, Colla G (2010) Enhancement of alkalinity tolerance in two cucumber genotypes inoculated with an arbuscular mycorrhizal biofertilizer containing Glomus intraradices. Biology and Fertility of Soils 46, 499-509.

Roxas VP, Smith RK, Allen ER, Allen RD (1997) Overexpression of glutathione Stransferase/glutathioneperoxidase enhances the growth of transgenic tobacco seedlings during stress. Nature Biotechnology 15, 988-991.

Ruiz JM, Blumwald E (2002) Salinity-induced glutathione synthesis in Brassica napus. Planta 214, 965-969.

Saab IN, Sharp RE, Pritchard J, Voetberg GS (1990) Increased endogenous abscisic acid maintains primary root growth and inhibits shoot growth of maize seedlings at low water potentials. Plant Physiology 93, 1329-1336.

Sahi C, Agarwal M, Reddy M, Sopory S, Grover A (2003) Isolation and expression analysis of salt stress-associated ESTs from contrasting rice cultivars using a PCR-based subtraction method. Theoretical and Applied Genetics 106, 620-628.

Sahi C, Singh A, Blumwald E, Grover A (2006) Beyond osmolytes and transporters: novel plant salt-stress tolerance-related genes from transcriptional profiling data. Physiologia Plantarum 127, 1-9.

Saijo Y, Hata S, Kyozuka J, Shimamoto K, Izui K (2000) Over expression of a single $\mathrm{Ca}^{2+}$ dependent protein kinase confers both cold and salt/drought tolerance on rice plants. The Plant Journal 23, 319-327.

Sanan-Mishra N, Pham X, Sopory S, Tuteja N (2005) Pea DNA helicase 45 overexpression in tobacco confers high salinity tolerance without affecting yield. Proceedings of the National Academy of Sciences of the United States of America 102, 509-514.

Scott CP, VanWye J, McDonald MD, Crawford DL (2009) Technical analysis of cDNA microarrays. PLoS ONE 4, e4486.

Seki M, Narusaka M, Ishida J, Nanjo T, Fujita M, Oono Y, Kamiya A, Nakajima M, Enju A, Sakurai T (2002) Monitoring the expression profiles of 7000 Arabidopsis genes under drought, cold and high-salinity stresses using a full-length cDNA microarray. The Plant Journal 31, 279-292.

Seki M, Okamoto M, Matsui A, Kim JM, Kurihara Y, Ishida J, Morosawa T, Kawashima M, To TK, Shinozaki K (2010) Microarray analysis for studying the abiotic stress responses in plants. Molecular Techniques in Crop Improvement 3, 333-355.

Shi D, Sheng Y (2005) Effect of various salt-alkaline mixed stress conditions on sunflower seedlings and analysis of their stress factors. Environmental and Experimental Botany 54, 8-21.

Shi H, Ishitani M, Kim C, Zhu J (2000) The Arabidopsis thaliana salt tolerance gene SOS1 encodes a putative $\mathrm{Na}^{+} / \mathrm{H}^{+}$antiporter. Proceedings of the National Academy of Sciences of the United States of America 97, 6896 - 6901.

Shi L, Perkins RG, Fang H, Tong W (2008) Reproducible and reliable microarray results through quality control: good laboratory proficiency and appropriate data analysis practices are essential. Current Opinion in Biotechnology 19, 10-18.

Singla-Pareek S, Reddy M, Sopory S (2003) Genetic engineering of the glyoxalase pathway in tobacco leads to enhanced salinity tolerance. Proceedings of the National Academy of Sciences of the United States of America 100, 14672-14677.

Singla-Pareek S, Yadav S, Pareek A, Reddy M, Sopory S (2008) Enhancing salt tolerance in a crop plant by overexpression of glyoxalase II. Transgenic Research 17, 171-180. 
Slovik S, Daeter W, Hartung W (1995) Compartmental redistribution and long-distance transport of abscisic acid (ABA) in plants as influenced by environmental changes in the rhizosphere: a biomathematical model. Journal of Experimental Botany 46, 881-894.

Solaiman Z, Marschner P, Wang D, Rengel Z (2007) Growth, P uptake and rhizosphere properties of wheat and canola genotypes in an alkaline soil with low P availability. Biology and Fertility of Soils 44, 143-153.

Sreenivasulu N, Grimm B, Wobus U, Weschke W (2000) Differential response of antioxidant compounds to salinity stress in salt-tolerant and salt-sensitive seedlings of foxtail millet (Setaria italica). Physiologia Plantarum 109, 435-442.

Sreenivasulu N, Sunkar R, Wobus U, Strickert M (2010) Array platforms and bioinformatics tools for the analysis of plant transcriptome in response to abiotic stress. Methods in Molecular Biology, Plant Stress Tolerance 1, 71-93.

Sun W, Bernard C, Van De Cotte B, Van Montagu M, Verbruggen N (2001) At HSP17. 6A, encoding a small heat shock protein in Arabidopsis, can enhance osmotolerance upon overexpression. The Plant Journal 27, 407-415.

Takahashi R, Liu S, Takano T (2009) Isolation and characterization of plasma membrane $\mathrm{Na}^{+} / \mathrm{H}^{+}$antiporter genes from salt-sensitive and salt-tolerant reed plants. Journal of Plant Physiology 166, 301-9.

Tarczynski MC, Jensen RG, Bohnert HJ (1993) Stress protection of transgenic tobacco by production of the osmolyte mannitol. Science 259, 508-510.

Tester M, Davenport R (2003) $\mathrm{Na}^{+}$Tolerance and $\mathrm{Na}^{+}$Transport in Higher Plants. Annals of Botany 91, 503-527.

Ueda A, Shi W, Nakamura T, Takabe T (2002) Analysis of salt-inducible genes in barley roots by differential display. Journal of Plant Research 115, 119-30.

Ulm R, Ichimura K, Mizoguchi T, Peck SC, Zhu T, Wang X, Shinozaki K, Paszkowski J (2002) Distinct regulation of salinity and genotoxic stress responses by Arabidopsis MAP kinase phosphatase 1. The EMBO Journal 21, 6483-6493.

USSL (2005) George E. Brown, Jr Salinity Laboratory. Riverside, CA, USA, USDA-ARS (http://www.ussl.ars.usda.gov).

Valdez-Aguilar LA, Reed DW (2008) Influence of Potassium Substitution by Rubidium and Sodium on Growth, Ion accumulation, and Ion Partitioning in Bean under High Alkalinity. Journal of Plant Nutrition 31, 867-883.

Valdez-Aguilar LA, Reed DW (2010) Growth and nutrition of young bean plants under high alkalinity as affected by mixtures of ammonium, potassium, and sodium. Journal of Plant Nutrition 33, 1472-1488.

Venema K, Quintero FJ, Pardo JM, Donaire JP (2002) The Arabidopsis $\mathrm{Na}^{+} / \mathrm{H}^{+}$exchanger AtNHX1 Catalyzes Low Affinity $\mathrm{Na}^{+}$and $\mathrm{K}^{+}$transport in reconstituted liposomes. The Journal of Biological Chemistry 277, 2413-2418.

Vij S, Tyagi AK (2007) Emerging trends in the functional genomics of the abiotic stress response in crop plants. Plant Biotechnology Journal 5, 361-380.

Wadleigh C, Brown J (1952) The chemical status of bean plants afflicted with bicarbonateinduced chlorosis. Botanical Gazette 113, 373-392.

Walia H, Wilson C, Ismail A, Close T, Cui X (2009) Comparing genomic expression patterns across plant species reveals highly diverged transcriptional dynamics in response to salt stress. BMC Genomics 10, 398.

Wang J, Zuo K, Wu W, Song J, Sun X, Lin J, Li X, Tang K (2003) Molecular cloning and characterization of a new $\mathrm{Na}^{+} / \mathrm{H}^{+}$antiporter gene from Brassica napus. Mitochondrial DNA: The Journal of DNA Mapping, Sequencing, and Analysis 14, 351-358. 
Whipker BE, Bailey DA, Nelson PV, Fonteno WC, Hammer PA (1996) A novel approach to calculate acid additions for alkalinity control in greenhouse irrigation water. Communications Soil Science and Plant Analysis 27, 959-976.

Winicov I (1998) New molecular approaches to improving salt tolerance in crop plants Annals of Botany 82, 703-710.

Wolf O, Jeschke WD, Hartung W (1990) Long distance transport of abscisic acid in NaCItreated intact plants of Lupinus albus. Journal of Experimental Botany 41, 593-600.

Wood AJ, Joel Duff R, Oliver MJ (2000) The translational apparatus of Tortula ruralis: polysomal retention of transcripts encoding the ribosomal proteins RPS14, RPS16 and RPL23 in desiccated and rehydrated gametophytes. Journal of Experimental Botany 51, 1655-1662.

Wood AJ, Oliver MJ (1999) Translational control in plant stress: the formation of messenger ribonucleoprotein particles (mRNPs) in response to desiccation of Tortula ruralis gametophytes. The Plant Journal 18, 359-370.

Xu J, Li Y, Wang Y, Liu H, Lei L, Yang H, Liu G, Ren D (2008b) Activation of MAPK Kinase 9 induces ethylene and camalexin biosynthesis and enhances sensitivity to salt stress in Arabidopsis Journal of Biological Chemistry 283, 26996-27006.

Xu J, Zhang Y, Guan Z, Wei W, Han L, Chai T (2008a) Expression and function of two dehydrins under environmental stresses in Brassica juncea L. Molecular Breeding 21, 431-438.

Yang CW, Wang P, Li CY, Shi DC, Wang DL (2008c) Comparison of effects of salt and alkali stresses on the growth and photosynthesis of wheat. Photosynthetica 46, 107-114.

Yang CW, Xu HH, Wang LL, Liu J, Shi DC, Wang DL (2009) Comparative effects of saltstress and alkali-stress on the growth, photosynthesis, solute accumulation, and ion balance of barley plants. Photosynthetica 47, 79-86.

Yang S-M, Chang C-Y, Yanagisawa M, Park I, Tseng T-H, Ku MSB (2008) Transgenic rice expressing cyanobacterial bicarbonate transporter exhibited enhanced photosynthesis, growth and grain yield Photosynthesis. Energy from the Sun, Springer Netherlands 20, 1247-1250.

Yang X, Römheld V, Marschner. H (1994) Effect of bicarbonate on root growth and accumulation of organic acids in $\mathrm{Zn}$-inefficient and Zn-efficient rice cultivars (Oryza sativa L.). Plant and Soil 164, 1-7.

Zhang H, Blumwald E (2001) Transgenic salt-tolerant tomato plants accumulate salt in foliage but not in fruit. Nature Biotechnology 19, 765-768.

Zhang H, Hodson J, Williams J, Blumwald E (2001a) Engineering salt-tolerant Brassica plants: characterization of yield and seed oil quality in transgenic plants with increased vacuolar sodium accumulation. Proceedings of the National Academy of Sciences of the United States of America 98, 12832-12836.

Zhang HX, Hodson JN, Williams JP, Blumwald E (2001b) Engineering salt tolerant Brassica plants: characterization of yield and seed oil quality in transgenic plants with increased vacuolar sodium accumulation. Proceedings of the National Academy of Sciences of the United States of America 98 12832-12836.

Zhenxian G, Xiaoliang H, Baocun Z, Chunjiang Z, Yingzhu L, Rongchao G, Yinzhu S, Zhanjing $\mathrm{H}$ (2010) Overexpressing a putative aquaporin gene from wheat, TaNIP, enhances salt tolerance in transgenic Arabidopsis Plant and Cell Physiology 51, 767-775.

Zhu JK (2001) Plant salt tolerance. Trends in Plant Science 6, 66-71.

Zribi K, Gharsalli M (2002) Effect of bicarbonate on growth and iron nutrition of pea. Journal of Plant Nutrition 25, 2143-2149. 


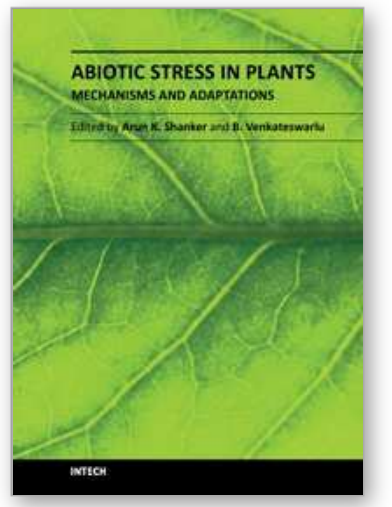

\author{
Abiotic Stress in Plants - Mechanisms and Adaptations \\ Edited by Prof. Arun Shanker
}

ISBN 978-953-307-394-1

Hard cover, 428 pages

Publisher InTech

Published online 22, September, 2011

Published in print edition September, 2011

World population is growing at an alarming rate and is anticipated to reach about six billion by the end of year 2050. On the other hand, agricultural productivity is not increasing at a required rate to keep up with the food demand. The reasons for this are water shortages, depleting soil fertility and mainly various abiotic stresses. The fast pace at which developments and novel findings that are recently taking place in the cutting edge areas of molecular biology and basic genetics, have reinforced and augmented the efficiency of science outputs in dealing with plant abiotic stresses. In depth understanding of the stresses and their effects on plants is of paramount importance to evolve effective strategies to counter them. This book is broadly dived into sections on the stresses, their mechanisms and tolerance, genetics and adaptation, and focuses on the mechanic aspects in addition to touching some adaptation features. The chief objective of the book hence is to deliver state of the art information for comprehending the nature of abiotic stress in plants. We attempted here to present a judicious mixture of outlooks in order to interest workers in all areas of plant sciences.

\title{
How to reference
}

In order to correctly reference this scholarly work, feel free to copy and paste the following:

Muhammad Javid, Marc Nicolas and Rebecca Ford (2011). Current Knowledge in Physiological and Genetic Mechanisms Underpinning Tolerances to Alkaline and Saline Subsoil Constraints of Broad Acre Cropping in Dryland Regions, Abiotic Stress in Plants - Mechanisms and Adaptations, Prof. Arun Shanker (Ed.), ISBN: 978953-307-394-1, InTech, Available from: http://www.intechopen.com/books/abiotic-stress-in-plantsmechanisms-and-adaptations/current-knowledge-in-physiological-and-genetic-mechanisms-underpinningtolerances-to-alkaline-and-sa

\section{INTECH}

open science | open minds

\section{InTech Europe}

University Campus STeP Ri

Slavka Krautzeka 83/A

51000 Rijeka, Croatia

Phone: +385 (51) 770447

Fax: +385 (51) 686166

www.intechopen.com

\section{InTech China}

Unit 405, Office Block, Hotel Equatorial Shanghai

No.65, Yan An Road (West), Shanghai, 200040, China 中国上海市延安西路65号上海国际贵都大饭店办公楼 405 单元

Phone: +86-21-62489820

Fax: $+86-21-62489821$ 
(C) 2011 The Author(s). Licensee IntechOpen. This chapter is distributed under the terms of the Creative Commons Attribution-NonCommercialShareAlike-3.0 License, which permits use, distribution and reproduction for non-commercial purposes, provided the original is properly cited and derivative works building on this content are distributed under the same license. 